\title{
土砂流下実験における間隙水圧の動的変化と流下土砂の運動特性 Pore-pressure fluctuation and run-out characteristics of the granular mass flow
}

\author{
岡田康彦 ${ }^{\mathrm{a}) *}$ ・落合博貴 ${ }^{\mathrm{a})}$ \\ Yasuhiko OKADA and Hirotaka OCHIAI
}

\begin{abstract}
Changes in pore-pressure and normal flow height in the granular mass flow had been investigated on sand and pumiceous gravel samples by quasi-real scale model flume tests. The excessive pressure head was observed under the sand flow, which was about 1.5 times as much as normal flow height. In the case of pumiceous sample, no excessive pressure head was observed, however, it traveled longer than the sand sample. This was because pumiceous sample had very small unit weight and it must have almost floated in the water during the experiments. The series of this experiments revealed that the both views of maximum travel distance and the extent of congregation of soil deposits were of great importance. For the sake of expressing the granular flow phenomena from those viewpoints, the new parameter "run-out characteristics index $(f)$ " was proposed as the ratio of the equivalent coefficient of friction $\left(\tan \phi_{a}\right)$ to the equivalent coefficient of friction between gravity centres before and after failure $\left(\tan \phi_{a g}\right)$.

Key words: Granular mass flow, excess pore-pressure, normal flow height, run-out characteristics index, quasi-real scale flume experiment

\section{和文要旨}

準実規模水路を用いた土砂流下実験を実施したところ，勾配部を流下する砂供試体中では，流下土砂高さの 1.5 倍程度の圧力水頭 発生が確認された。桜島から採取した軽石（ボラ）試料は，単位体積重量が小さいため，過剩な間隙水圧の発生がなくとも長距離 運動することが示された。最大到達距離ならびに堆積する土砂の集合の程度の両視点から土砂流下現象を考える必要性を示し，こ れを表現する指標として，運動特性指数（等価摩擦係数と重心間の等価摩擦係数の比）を提案した。

キーワード：土砂流動，過剩間隙水圧，流下土砂高さ，運動特性指数，準実規模水路実験
\end{abstract}

\section{1. はじめに}

地すべり・斜面崩壊は，豪雨や地震を主な誘因として 発生する。これらの内，発生時あるいは運動中に流動化 （土石流化）するものは緩斜面を高速で長距離移動する ため，人的・経済的観点から見て最も危険なタイプの一 つであると考えられ，このため，その流動機構を明らか にするべく多くの研究がなされてきた（本報では，この ような流動性の高い土砂流下現象を，高速土砂流動現象 と呼ぶ)。高速土砂流動現象は, 斜面の溪床堆積物が地 下水の上昇等に伴って飽和することにより静的な力のバ ランスが崩れて発生するケース，あるいは，いわゆる地 すべりが発生し，その後下方の飽和層を巻き込んで流動 化へと進展するケースが考えられる。さらには，飽和に 近い状態で運動してきた地すべり土塊が堰堤等の構造物 と接触して変形することに伴い間隙水圧が上昇して，高 速土砂流動現象へと発展する場合も考えられる（Sassa 2000）。土砂が高速で長距離流動する機構を考える上で, 地すべりのすべり面付近の現象に注目して, Shreve (1966，1968)が「Air-layer Lubrication model」を, Sassa （1996）およびSassa et al.（1996）が「すべり面液状化 モデル」を提唱した。「Air-layer Lubrication Model」は, 地すべり・斜面崩壊土砂が発生し下方へ移動する際底部

* 連絡著者/corresponding author

a) 独立行政法人森林総合研究所

Incorporated Administrative Agency Forestry and Forest Products Research Institute

テ305-8687 茨城県つくば市松の里 1

1 Matsunosato, 305-8687, Tsukuba, Ibaraki, Japan
に大量の空気を取り込み，そして土砂の下部で圧縮され た空気の上を地すべり・斜面崩壊土砂が運動して極めて 小さな摩擦力しか発揮されないため，高速で長距離運動 すると説明している。「すべり面液状化」は，地すべり のすべり面における局所的な液状化現象であり，水平砂 層地盤において地震時に全層的に発生するいわゆる液状 化現象 (Casagrande 1971, Castro and Poulos 1977ほか) とは異なる。この現象は, 地すべり土塊の上載圧により すべり面付近の土粒子が破砕・粉砕されることで体積収 縮が発生し，非排水条件が確保されるとこれに伴った有 効垂直応力の低下によりせん断抵抗も減少することが主 たるメカニズムである。なお岡田ほか（2002）は，土粒 子が破砕・粉砕されると透水性がさらに低下して，すべ り面付近では難透水層が形成されるため，一度発生した 過剩間隙水圧の発散が抑制され，流動が継続されると説 明している。

これらに対し，流下土砂内部で発生している現象に着 目して，Bagnold（1954）は「Grain Flow Model」を提 唱した。このモデルは，土粒子と水が渾然一体となって 緩傾斜を下るためには，土粒子が流体相のなかでバラバ ラに分散することにより，それらが発揮するせん断抵抗 力が小さくなっていなければならないという考えに基づ いている。そして，このように流体よりも重い土粒子が 内部で分散した状態を継続するためには，流下する土砂 内部で土粒子同士が衝突し，これに伴って発生する反発 力（粒子衝突力）が作用し続けなければならないと説明 
した。Savage（1984）は，粒子衝突応力と土粒子荷重 による圧力の比を無次元のSavage数 $\left(N_{S A V}\right)$ として提 案した。そして, Savage and Hutter (1989) は, Savage 数 $N_{S A V}$ が 0.1 より大きい場合において粒子衝突応力が重 要であり，それ以外の場合では土粒子荷重による圧力が 重要であるとした。Iverson and Denlinger（2001）は, 多くの土砂流動現象に対してN $N_{S A V}$ 数を実測し, それら の值が 0.1 よりさいことから, 流下土砂中では，粒子 衝突応力よりも土粒子荷重による圧力での接触に伴って 発生するクーロン摩擦応力が流れのせん断抵抗を支配す るとした。そしてIverson and Vallance（2001）は，こ のせん断抵抗は流下土砂の高さ, 固体粒子体積濃度, そ して間隙水圧に依存することを示し, 特に, 静水圧以上 の過剩な間隙水圧の影響を強調している。

石川（1999）は，地震に起因した高速土砂流動現象の 発生に及ぼす地形的要因の与える影響に関して検討し, 崩壊部下流の勾配と, 崩壊土砂が下流へ流入する角度が 大きく影響を与えると述べている。山田ほか（2000）は, 流出土砂量が大きく地下深部の影響を強く受けて発生す る複合型土石流の発生条件に対する地形的要因の与える 影響を調べ，崩壊土砂の下流への流入角度，ならびに崩 壊土砂の下流へ流入する河床勾配が最重要要因であるこ とを示した。

これらの研究から, 流下土砂中ではクーロン摩擦応力 が流れのせん断抵抗を支配し，そしてこのせん断抵抗は 流下土砂の高さや間隙水圧等に依存すること, 上流部斜 面と下流部斜面の勾配ならびに流入角が高速土砂流動現 象の発生に大きな影響を与えることがわかっている。し かし，これまで実施されてきた模型実験は，縮小模型を 用いたものが主であり，これらについては，自重による 力, せん断抵抗力ほかに関して, 原型 (実物) に対する 模型の比を揃える（相似比を満足させる）問題を気にし ないで最初から一つの小さな実例と見なして定性的な評 価を試みるという考え方が支配的である。しかしながら， 原型と模型の力の比を满足させるという相似則は, 香川 （1978）が指摘している通り，土砂が流下する現象のよ うに力による物理量が支配的である問題については有効 であることが確認されており，無視することはできない と考えられる。

土砂流下実験においては，変形に伴う力や粘着力の相 似比を満足させるのは極めて困難なことから，相似則の 影響を無視しても影響が少ないと考えられる実規模での 模型実験が必要と考え, 準実規模水路を用いた土砂流下 実験を行った。ここで，準実規模水路は，勾配が可変な 仕様を有している。土砂流下実験では，「流下土砂の高 さ」ならびに「流下土砂底面における間隙水圧変化」を 実測し,この結果について, 過剩間隙水圧の発生が, 有 効垂直応力，そしてせん断抵抗の減少を招くという土質 力学的見地からの検討・解析をおこなうことにより，土 砂が斜面を下方へ移動する際の流動化機構の実証的解明
を目指した。なお，間隙水圧変化は，試料の透水性に大 きな影響を受けることから，透水性の大きく異なる川砂 試料，ならびに火山地域で採取した軽石試料を実験試料 に選択した。

粒径の大きく異なる供試材料を使用したり, 勾配を変 化させて異なる実験条件を与えた場合, 土砂が水路勾配 部を流下するときに, 間隙水圧変化（過剩間隙水圧の発 生に伴った有効垂直応力およびせん断抵抗の減少の程 度）ならびに集合の程度（塊状を保つか分散するか）に 関して違いが生じ，このことが水路水平部における運動 に影響を与えると推測される。このことから，本論文の 後半では, 流下土砂の到達距離の視点からの議論を展開 する。高速土砂流動現象のみならず，地すべり・斜面崩 壊現象に関して到達距離の議論をする場合, 一般に等価 摩擦係数 (Scheidegger，1973）が用いられる。等価摩 擦係数は, 物体の移動を質点の運動と仮定し, 移動した 斜距離に対する最大鉛直高さをその最大到達水平距離で 除した值で表現したものであり, 実際には地形条件や含 水条件等によりその值は異なってくるものの, 移動開始 から停止するまでに見かけ上平均的に発揮された摩擦係 数として代用されている。そして, この值が小さいほど 移動体は遠くまで運動することを意味する。一方, 本論 文では，ある大きさを持つ実際の土砂の運動現象におい て, 力学的に現象をより正確に表現するには, 崩壊発生 前および堆積時の重心間の関係が用いられるべきである と考え, 重心間の鉛直距離を水平距離で除した值を重心 間の等価摩擦係数として導入する。そして等価摩擦係数 と重心間の等価摩擦係数の比を用いて, 堆積する土砂の 集合の程度という視点から議論をする。

\section{2. 準実規模水路実験}

\section{1 水路および計測器}

実験に使用した水路を写真 -1 に, 概略図ならびに計 測器の配置状況を図 -1 に示す。水路は, 傾斜を変更可 能な上流部と水平に設置した下流部からなる。上流部の 水路長は $5 \mathrm{~m}$, 下流部の水路長は $8 \mathrm{~m}$ であり, 水路幅は, 上下とも $0.6 \mathrm{~m} て ゙ あ る 。$ 水路の片面は強化ガラス製で,

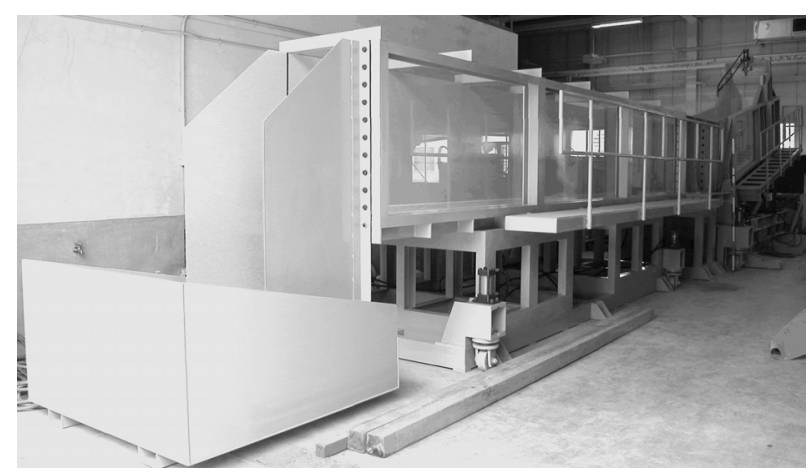

写真一 1 水路の全景

Photo 1 The model flume for the granular mass flow experiments. 


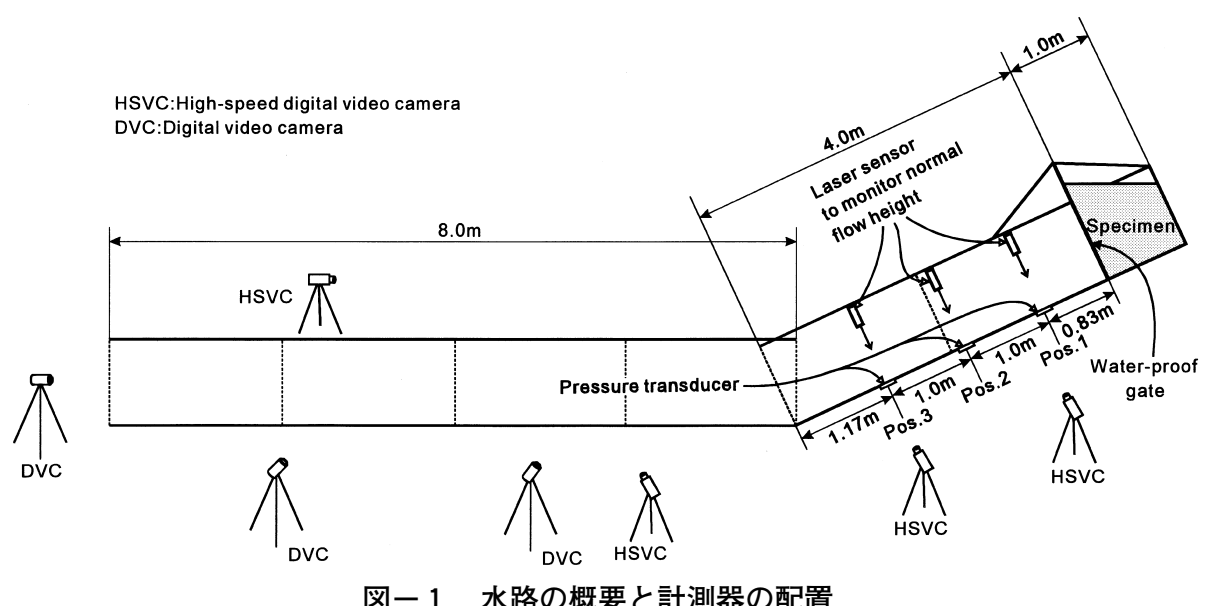

Fig. 1 Schematic illustration of model flume and arrangement of measurement transducers

側部から土砂の移動を撮影可能な仕様を有する。水路底 面には，粗度を与えるために，粒径 $0.4 \mathrm{~mm} \sim 2.0 \mathrm{~mm}$ の 砂を密に吹き付けたシートを貼り付けた。水路上流部 は，45度まで傾斜を与えることが可能であり，水路下流 部への流入勾配が可変となっている。本実験では，土砂 を崩壊－流下させるため, 水路上部の最上端部 $1 \mathrm{~m}$ 水 密のゲートで仕切り，そこに詰めた材料に対し給水を 行って飽和供試体を作成した。ゲートは観音開き方式で 開放することが可能であり，電気信号で制御を行う方式 をとった。

本実験では，流下させた土砂底面で発生している「間 隙水圧変化」，ならびに流下土砂の「高さ」を計測した。 水路上流部の底面に間隙水圧計をセットするとともに, この間隙水圧計の上を通過する流下土砂の水路勾配部に 垂直な方向の高さを計測可能とするようにレーザー変位 計を取り付けた。これらのデータは，1秒間に100回の 計測間隔でPCに取り込んだ。PCに収録される経過時間 （最小単位は100分の 1 秒）は，水路の周囲に設置した 4 台の時刻表示器にも同時出力されるようにした。土砂流 下時の撮影は，4台の高速ビデオカメラと通常のディジ タルビデオカメラを用いて実施した。4 台の高速ビデオ

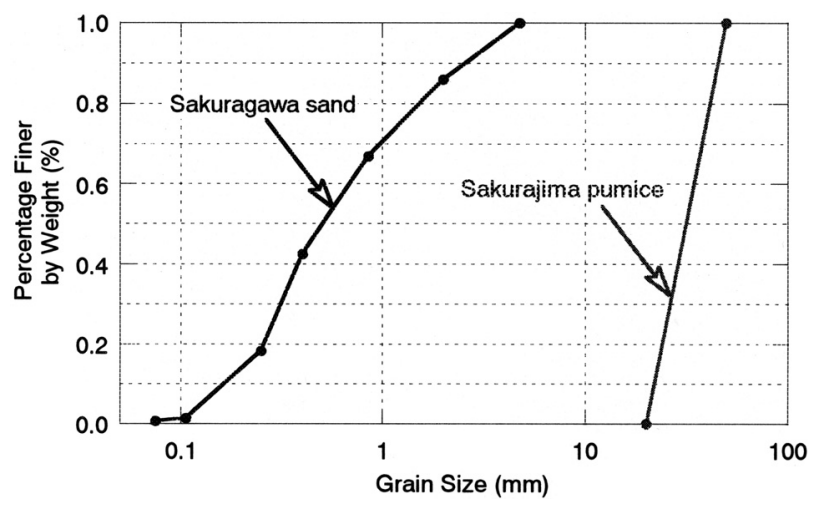

図一2 試料の粒径加積曲線

Fig. 2 Grain size distribution curves of employed samples
カメラは，お互いに関して完全同期撮影可能な仕様を有 するものとした。計測間隔は 1 秒間に 125 フレームに設 定し， 8 秒間撮影した。また，高速ビデオカメラの内 1 台では，間隙水圧計ならびにレーザー変位計の経過時間 を表す上記時刻表示器を同時に撮影した。このことによ り，実験終了後画像解析する際に，1,000枚の画像と間 隙水圧計およびレーザー変位計のデー夕の同期をとるも のとした。

\section{2 試料および実験条件}

二つの材料を用いて実験を実施した。一つは茨城県つ くば市を流れる桜川から採取した川砂であり，他方は鹿 児島県鹿児島市桜島火山の松浦川地区から採取した降下 軽石（ボラ）である。ボラ試料は，大小種々の粒径を含 むが, 水路の大きさを考慮して $50 \mathrm{~mm}$ ふるい通過・ $20 \mathrm{~mm}$ ふるい残留材料とした。なお，上流部水路は 10 度傾斜の 状態で $0.6 \mathrm{~m}^{3}$ の試料を詰め込み, その後, 下方から給水 して飽和供試体の作成を行い，そして，それぞれの実験 条件に合わせて 25 度ならびに 35 度に傾斜を変更し実験を 開始した。試料の物性值は, 桜川砂試料に関して, 土粒 子密度 $\left(\rho_{s}\right)$ が $2.62 \mathrm{~g} / \mathrm{cm}^{3}$, 平均粒径 $\left(D_{50}\right)$ が $0.50 \mathrm{~mm}$, 均等係数 $\left(U_{c}\right)$ が 4.31 , 曲率係数 $\left(U_{c}{ }^{\prime}\right)$ が 0.93 であった。 桜島ボラ試料は, 土粒子密度 $\left(\rho_{s}\right)$ が $2.43 \mathrm{~g} / \mathrm{cm}^{3}$, 平均 粒径 $\left(D_{50}\right)$ が $32.5 \mathrm{~mm}$, 均等係数 $\left(U_{c}\right)$ が 1.58 , 曲率

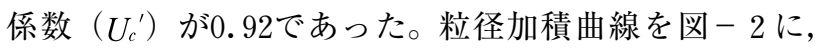
実験番号と実験条件を表 -1 に示す。

\section{表一 1 実験番号と条件}

Table 1 Experiment identification number and conditions

\begin{tabular}{|c|c|c|c|c|}
\hline Number & Sample & $\begin{array}{c}\text { Slope } \\
\text { inclination } \\
(\text { degrees })\end{array}$ & $\begin{array}{c}\text { Dry unit } \\
\text { weight } \\
\left(\mathrm{gf} / \mathrm{cm}^{3}\right)\end{array}$ & $\begin{array}{c}\text { Initial void } \\
\text { ratio, e0 }\end{array}$ \\
\hline Ex.1 & SS & 25 & 1.6 & 0.63 \\
\hline Ex.2 & SB & 25 & 0.37 & 5.5 \\
\hline Ex.3 & SB & 35 & 0.38 & 5.3 \\
\hline
\end{tabular}

in which SS stands for Sakuragawa sand, and SB is Sakurajima Bora pumiceous gravel. 


\section{3．発生した間隙水圧と流下土砂の高さ}

\section{1 粒径の効果}

粒径区分が主に砂に分類される桜川砂と，礫に分類さ れる桜島ボラを対象に，流下傾斜25度水路で土砂流下実 験を実施することにより，大きく粒径の異なる供試体に おける発生間隙水圧と流下土砂高さの関係を調べた。

図-3に桜川砂試料を対象とした実験（実験 1 (Ex.1))の結果を示す。経過時間については，最も上流 側に位置する計測地点 1 で流下土砂高さが増加し始めた 時刻をゼロに設定した。計測地点 2 および計測地点 3 に ついては，経過時間が約 0.2 秒そして 0.4 秒で，流下土砂 の高さが急増し始めた。また，計測地点 1 から計測地点 3 全てで，流下土砂通過開始後それぞれ 1 秒程度で高さ
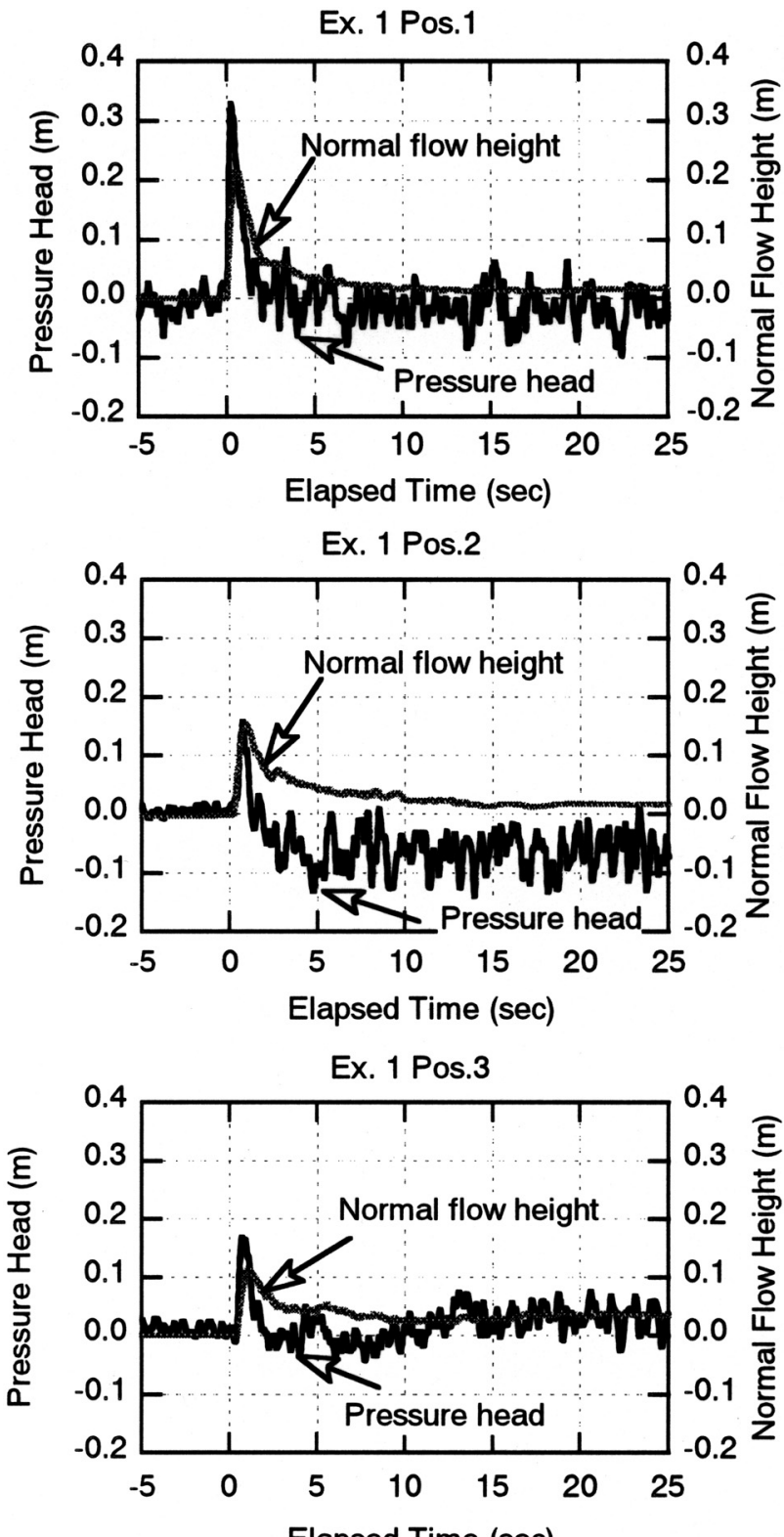

Elapsed Time (sec)

図-3 桜川砂試料(25度傾斜・実験 1 ) に対する試験で得ら れた圧力水頭ならびに流下土砂高さの時系列データ

Fig. 3 Time series data of pressure head and normal flow height of Sakuragawa sand (Ex. 1)
のピークが観測された。計測地点 1 は，水密ゲートの直 近に設定されていたため流下土砂高さピークは $0.2 \mathrm{~m}$ 超え，計測地点 2 や計測地点 3 よりも大きな值を示した が，大きな土砂流が通過した後ほとんど土砂の流下が停 止した 8 秒では0.03mまで低下した。このときの值は, 計測地点 2 の $0.04 \mathrm{~m}$, 計測地点 3 の $0.05 \mathrm{~m}$ に較べて小さ い值となり，土砂の大半は計測地点 1 よりも下流側まで 流下した。計測地点 2 と計測地点 3 の流下土砂高さの経 時変化を較べると，計測地点 3 では，経過時間 4 秒から 6 秒の間ほぼ一定の高さを保持しているのに対し，計測 地点 2 では，単調減少が認められた。流下土砂高さが一 定ということは，土砂が堆積して停止したか，上流から の土砂流入量と下流への土砂流出量のバランスがとれた ことを意味する。撮影したビデオ画像を確認したところ， 土砂の移動は継続していたため，今回のケースでは，こ の時間带において計測地点 3 では土砂の流入と流出のバ ランスがとれた状態であったと判断された。これに対し， 計測地点 2 では下流側への土砂流出量が土砂流入量を上 回っていたと判断された。経過時間 6 秒以後は, 計測地 点 3 でも流下土砂高さは減少し，約12秒以後はわずかに 土砂が流下している状態に到達した。

発生した圧力水頭変化に着目すると, 計測地点 1 およ び 3 の経過時間約 0.1 秒から 1.2 秒程度において，圧力水 頭值が流下土砂高さを上回る結果が得られた。計測地点 2 に関しても流下土砂が到達すると同時に圧力水頭值の 急激な上昇が認められ，若干量ながらその值が流下土砂 高さを上回った。なお，今回実施した実験については， 懸濁されうる細粒分が供試材料にほとんど含まれないこ とから，圧力水頭值が流下土砂高さを上回った場合，過 剩な間隙水圧が発生していたと推定される。このことか ら，流下土砂の先頭部付近に抒いては，過剩間隙水圧が 発生していたと考えられ，いわゆる液状化現象に見られ るような，土粒子骨格間の有効垂直応力の低下 - せん断 抵抗の減少が発生したと考えられる。

計測地点 1 および 3 では，相当量のふらつきはあるも のの, 経過時間約 2 秒程度からは圧力水頭値はほぼゼ口 を示した。一方, 計測地点 2 では, 圧力水頭值がマイナ スの值を示した。この理由を確認するために，撮影した ビデオ画像で土砂流下時の様子を調べた。その結果，流 下土砂の先頭部が通過した後，計測地点 1 では，土砂の 堆積が始まり動きが止まったのに対し, 計測地点 1 と計 測地点 2 の中間付近より下流側の土砂は，一度ゆるめた 流下速度を再度増加させていたことがわかった。このこ とにより, 計測地点 2 付近では, 残留する土砂と流下す る土砂が分離することにより流下土砂内部でせん断／引 張応力が発生し，その結果負の圧力水頭值を示したと推 論した。また，経過時間16秒以降は，流下土砂の高さが ほとんど変化していないことから，不飽和の状態で堆積 した土砂内部に生じたサクションの効果も働いたと考え られる。ここで計測された負の圧力水頭值は，流下土砂 
本体後部が堆積する過程を明らかにする上で重要と考え られる。類似の研究として，Iverson（1997）は，砂と 礫の混合試料やロームと䃏の混合試料を対象に土砂流下 実験を実施している。しかし，彼らの実験では，勾配部 に土砂がほとんど堆積しなかったため，桜川砂を用いた 実験 1 (Ex.1))の計測地点 2 で観測されたような負の 圧力水頭については報告されていない。一方，計測地点 3 では，上流側からの土砂の流下が増えたため経過時間 9 秒程度から圧力水頭值の再上昇が発生し, 約 $0.05 \mathrm{~m}$ の 值まで到達した。

図ー4に勾配 25 度斜面を対象にした桜島ボラ試料の実

Ex. 2 Pos. 1

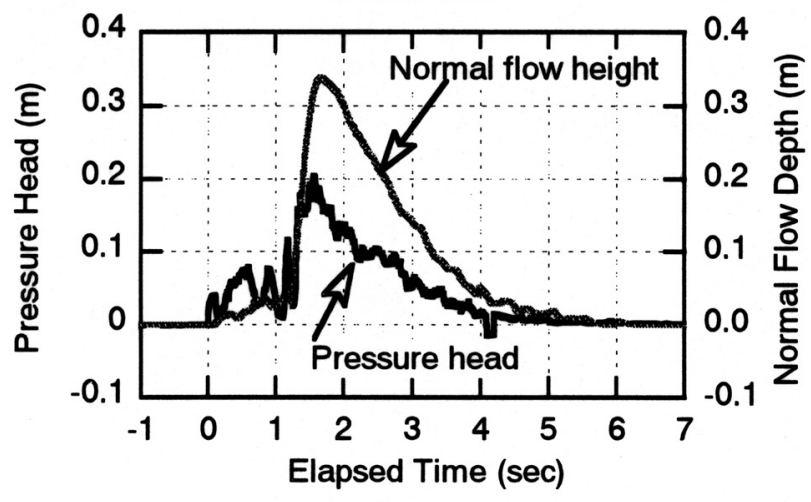

Ex. 2 Pos. 2

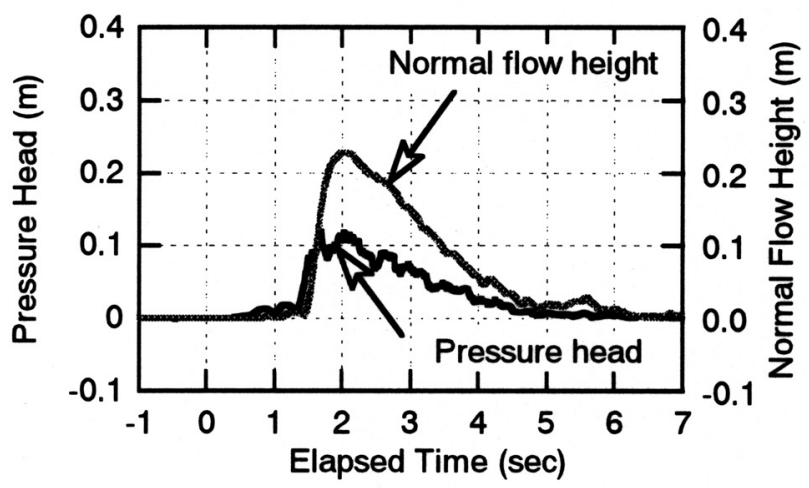

Ex. 2 Pos. 3

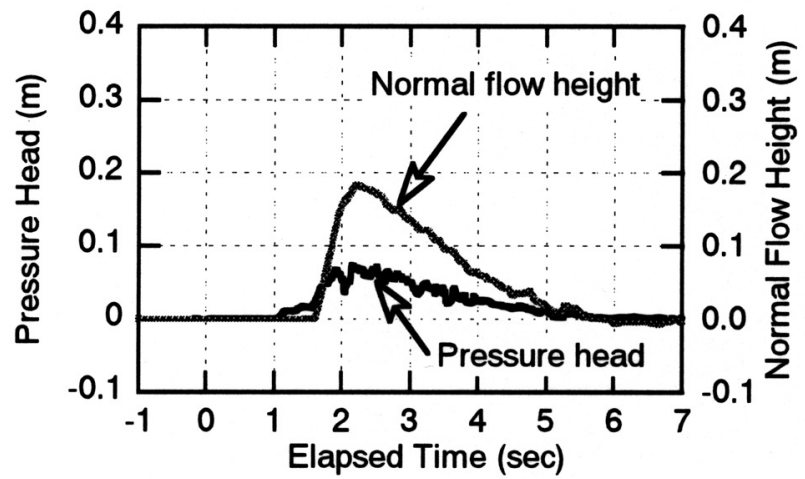

図-4 桜島ボラ試料（25度傾斜・実験 2 ）に対する試験で 得られた圧力水頭ならびに流下土砂高さの時系列 データ

Fig. 4 Time series data of pressure head and normal flow depth of Sakurajima Bora pumiceous gravel on 25-degree-inclined slope (Ex. 2)
験（実験 $2 （ E x .2 ）$ の結果を示す。計測地点 1 から計 測地点 3 の順に, 経過時間 1.2 秒，1.4秒，1.6秒頃，流 下土砂高さが急増し，それぞれ約 0.5 秒後にピークを発 生させた。その後は，4秒以内に流下土砂高さがゼロに なった。桜川砂試料での実験では流下土砂高さのピーク 発生後，その值がゼロに戻らなかったが，一方，桜島ボ ラ試料での実験では，撮影したビデオ画像でも確認され たが，大半の土砂が一気に傾斜水路を流下して下流側へ と流れ去った。

発生した圧力水頭値については，流下土砂の先端が到 達するとほぼ同時に急増したが，その值は流下土砂高さ の半分程度であった。桜川砂試料での実験のように過㮃 間隙水圧の発生は認められなかった。また，土砂の先端 部の流下速度を計測地点 2 および計測地点 3 の間に関し て算出すると，桜川砂試料（実験 1 (Ex. 1))が $4.76 \mathrm{~m} /$ sec，桜島ボラ試料（実験 $2(\mathrm{Ex} .2)$ )が5.88m/secとな り，桜島ボラ試料実験での先端部がより高速で流下した ことがわかった。なお，例えば計測地点 1 において，0 秒付近から，圧力水頭ならびに流下土砂高さの増加が認 められるが，これは，観音開き形式のゲートが中央から 開き始めて完全に開き切るまでの間に，一部の水および 土砂が流れ出たためである。

ここまでで示したように，流下土砂底面で計測された 圧力水頭值は，桜川砂試料と桜島ボラ試料それぞれの実 験で異なることがわかった。間隙水圧は，土砂が流下す る際に発生する土粒子のすべり，転がり等を伴った流下 土砂内部の変形により上昇したり下降したりすると推測 されるが，一度発生した間隙水圧值の発散は，主に供試 体の透水性に依存していると考えられる。砂の場合は砂 に比較して間隙が大きく，そのために間隙水圧の発散は 速やかに行われたため，図-4で示した通り，高速で土 砂が流下していても過剩な間隙水圧が発生しなかったも のと考えられる。一方，砂に分類される桜川砂試料は， 粘土やシルトからなる材料に較べるとその透水性は大き いものの，激しい運動を伴う土砂流下現象中では，急激 に発生した過剩間隙水圧を維持したものと推測された。 このことは，流下土砂高さが $10 \mathrm{~cm} \sim 20 \mathrm{~cm}$ 程度でありそ の上面は空気と接するような条件下であっても，流下土 砂先頭部付近においては，土質試験として利用される三 軸圧縮試験やリング型直接せん断試験で実験条件として 与える非排水条件に近い状態が出現し得ることを示すと 考えられる。なお，前述の通り，Iverson（1997）は類 似の研究を行っているが，事例として，砂と礫の混合試 料やロームと礫の混合試料を対象にした土砂流下実験に おいて，本論文と同様，圧力水頭值が流下土砂の高さを 上回る結果を示している。この中で，ロームと礫の混合 試料を対象にした実験では，流下土砂の高さが比較的一 定の值を示している場合について，圧力水頭值が流下土 砂の高さを上回っている事例が示されている。これらに 関して，著者らは，土砂が $67 \mathrm{~m} も の$ 長距離を流下してき 
たため相当大きな速度を有し，流下土砂内部での変形も 激しく水圧が上昇しやすかったこと，ならびに細粒分 （ローム）を多く含んでいたため水の見かけ単位体積重 量が増加していたことが主たる原因であると推測した。 Iverson（1997）およびTverson et al.（1997）が指摘し ているように，ビンガム流体モデルやダイラタント流体 モデルを用いた水理学的視点からの研究 (Johnson and Rahn 1970, Takahashi 1978, and 1980, Macedonio and Pareschi 1992, Hunt 1994, Shieh et al. 1996) では，間 隙水圧変化が反映されないが，土砂が流下する際の特に 先頭部においては，過剩間隙水圧が発生し得ることがわ かり，土砂流下現象を解明する上でこのことを反映した
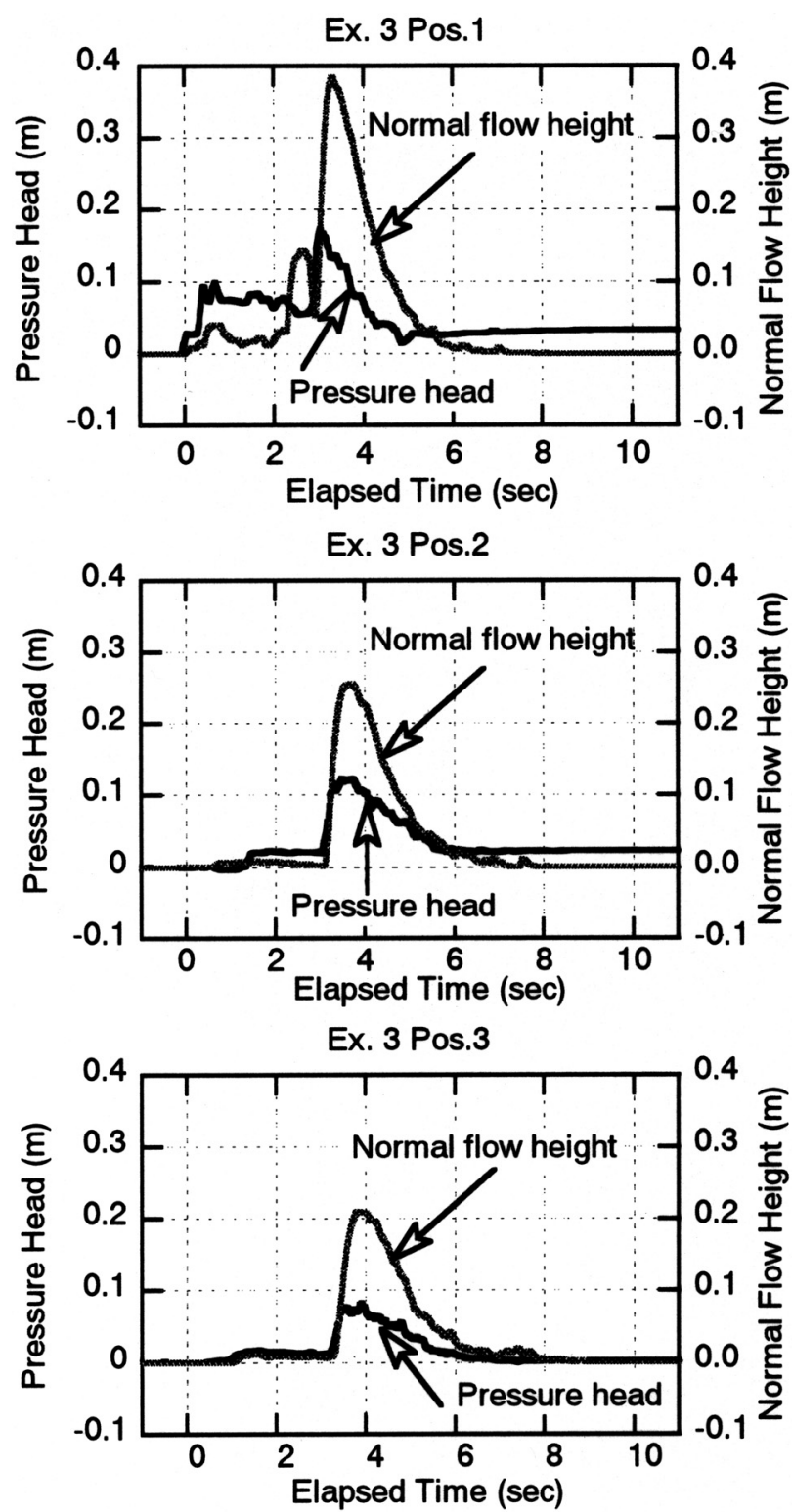

図ー5 桜島ボラ試料（35度傾斜・実験 3 ）に対する試験で 得られた圧力水頭ならびに流下土砂高さの時系列 データ

Fig. 5 Time series data of pressure head and normal flow depth of Sakurajima Bora pumiceous gravel on 35-degree-inclined slope (Ex. 3)
モデルからも検討する必要があると考えられる。

\section{2 流下勾配の効果}

流入勾配の違いが流下土砂中で発生する挙動（間隙水 圧の動的変化や運動特性）に与える効果を明らかにする ベく, 桜島ボラ試料を対象に勾配35度での土砂流下実験 を行った。図ー 5 に実験結果を示す。流下土砂高さは, 計測地点 1 から計測地点 3 の順にそれぞれ, 経過時間約 2.3 秒, 3.1秒, 3. 秒付近から急激に増加し, その後約 0.4秒までにピークを示した。また，土砂はほほ塊状を 保ったまま流下したため，ピークを示した後の流下土砂 高さの低下は速く, 約 2.5 秒程度でゼロに戻った。勾配 25 度水路における桜島ボラ試料の実験結果との違いは, 勾配35度水路での実験結果において, 計測地点 1 から計 測地点 3 に渡り先頭部を形成した土砂が一気に塊のまま 高速で通過した点と, 流下土砂高さのピークがやや大き かった点である。これは勾配が10度急であったため, ゲートオープンと同時に一気に土砂が流下して分散する 時間が少なかったためであると考えられる。な㧍，計測 地点 2 および計測地点 3 間の流下土砂の先端部における 速度は $5.00 \mathrm{~m} / \mathrm{sec}$ となり, 実験 2 の $5.88 \mathrm{~m} / \mathrm{sec}$ を回っ た。しかしながら, 計測地点 2 と計測地点 3 において流 下土砂高さがピークを示した瞬間に扔ける両計測地点間 の速度は, 実験 2 (Ex.2) が6. 25m/sec, 実験 3 (Ex. 3) が7.69m/secと, 逆に実験 3 （Ex. 3）が実験 2 （Ex. 2) を上回った。また，害験 2（Ex.2）に関する両速度は それほどその值に差がないが，実験 3 （Ex.3）では両 速度間に $2.69 \mathrm{~m} / \mathrm{s}$ の差があった。このことから, 計測地 点 2 および 3 の間において, 実験 2 (Ex.2）では，先 頭部付近の全層がほぼ同じ速度で移動したのに対し，実 験 3 （Ex. 3）では土砂先頭部表面付近と勾配水路底部 付近の速度差が大きく, 流下土砂内部でせん断が生じて いたと考えられる。

発生した圧力水頭変化は，勾配25度水路に対する桜島 ボラ試料の実験結果とほぼ同じであり，その值は流下土 砂高さの半分以下程度と, 過剩な間隙水圧の発生は認め られなかった。

\section{4. 運動特性}

流下土砂の運動した距離について考察する。図一 6, 7, 8 に実験終了時の土砂の堆積状況を示す。それ ぞれ, 図-6は桜川砂試料 (実験 1 (Ex.1)), 図-7 は勾配25度水路に対する桜島ボラ試料 (実験 2(Ex.2)), 図-8 は勾配 35 度水路に扔ける桜島ボラ試料（実験 3 (Ex. 3))の結果である。なお，図中には，実験開始前な らびに堆積時の重心位置も示されている。

実験 1 （Ex.1）では，ゲートオープンと同時に，流 下土砂の一部はピーク高さを持った先頭部を形成し傾斜 変換点に到達した。その後, 堆積を進行させながらも最 先端部は高速のまま移動して水路の端部付近まで到達し た。先頭部を形成しなかった土砂の残りの部分は，ゲー 


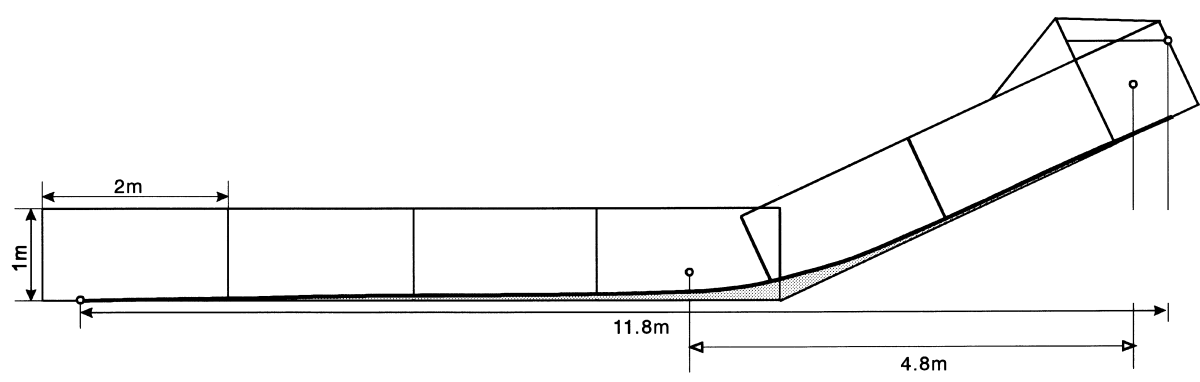

図-6 桜川砂試料 (25度傾斜・実験 1 ) の堆積状況

Fig. 6 Side view of the sedimentation of Sakuragawa sand (Ex. 1)

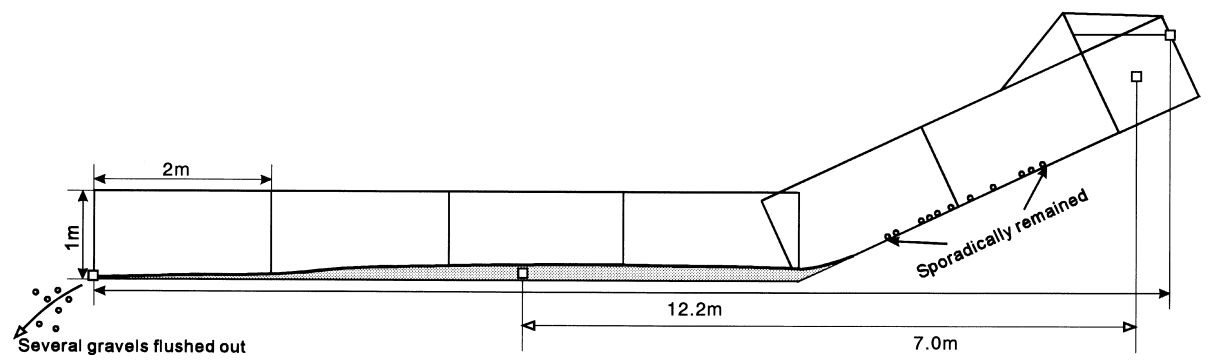

図ー7 桜島ボラ砂試料（25度傾斜・実験 2 ）の堆積状況

Fig. 7 Side view of the sedimentation of Sakurajima Bora pumiceous gravel on 25degree-inclined slope (Ex. 2)

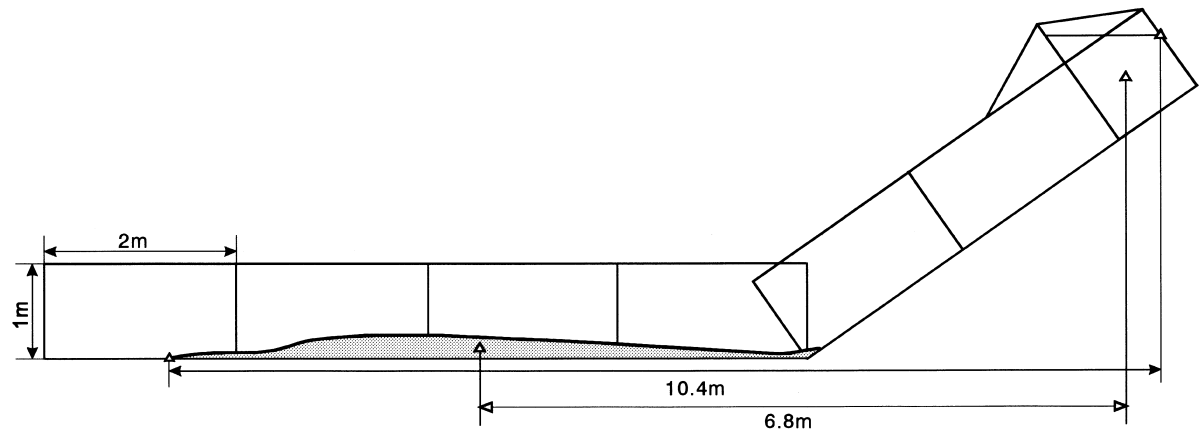

図ー8 桜島ボラ砂試料（35度傾斜・実験 3 ）の堆積状況

Fig. 8 Side view of the sedimentation of Sakurajima Bora pumiceous gravel on 35degree-inclined slope (Ex. 3)

トオープン時から比較的ゆっくりと流下した。相当量が, 上流側の計測地点 1 付近でも堆積しており, 約 $0.02 \mathrm{~m}$ 程 度の厚さを示した。計測地点 2 付近以下では, 計測地点 1 付近での堆積が始まってからも再び動きが見られ下流 側へずるずるとゆっくり移動した。この結果，崩壊土砂 の最先端部は水路水平部の左端部付近まで移動したが非 常に薄い堆積厚を示し, 多くの土砂は傾斜変換点付近で 堆積した。土砂の堆積厚のピークも傾斜変換点付近であ り，その值は約 $0.22 \mathrm{~m}$ であった。

実験 $2 （ \mathrm{Ex} .2 ）$ では，ゲートオープンと同時に供試 体のほとんどが一気に流下した。一部の䂺は傾斜水路に 残留したが，所々まばらに存在する程度であった。流下 した土砂は，傾斜変換点で水路水平部に到達後は流下土 砂本体後部の礫を堆積させながら, 先端部は運動を続け, 最終的には体積にして $1,400 \mathrm{~cm}^{3}$ 程度が水平水路から飛
び出した。しかしながら流下土砂のほとんどは水平水路 上に堆積した。水平水路端部から約 $1.5 \mathrm{~m}$ 付近から堆積 厚を緩やかに増加させつつ, 約 $2.5 \mathrm{~m}$ 程度からは堆積厚 をさらに増加させ，以降水平水路上を約 $0.15 \mathrm{~m}$ 以上の厚 さで堆積した。堆積厚のピークは端部から約 $5.0 \mathrm{~m}$ 付近 で，その值は約 $0.20 \mathrm{~m}$ を示した。

実験 3 （Ex. 3）では, 実験 2 と同様にゲートオープ ンと同時に土砂が一気に流下した。この実験では，傾斜 水路に残留した礫はほとんど認められなかった。流下し た土砂は水平水路に到達後も停止するものは少なく，一 部は堆積しつつも多くは前方へ運動を続けた。流下土砂 の先頭部は, 水平水路端部から約 $2.0 \mathrm{~m}$ 付近で堆積した。 水平水路端部から $2.5 \mathrm{~m}$ 付近では, 堆積面の勾配が急増 し，4.5m付近まで $0.20 \mathrm{~m}$ 以上の厚さで堆積した。最も 遠くへ移動した礫は水平水路端部から約 $1.5 \mathrm{~m}$ 程度まで 
到達したが，これは水路端部から約 $2.0 \mathrm{~m}$ 付近に一度堆 積した土砂が，後から遅れて流れてきた水により押され たためである。堆積厚のピークは水平水路端部から約 3.8 $\mathrm{m}$ 付近で，その值は約 $0.25 \mathrm{~m}$ であった。

土砂の最大到達距離を図 $-6,7 ， 8$ を参照しながら 比較する。実験 1 （Ex.1）および 2 （Ex.2）は勾配25 度, 実験 3 （Ex. 3）は勾配35度であり，崩壊発生前の 位置が異なることに注意して最大到達距離を求めると, 砂 $\left(\right.$ 約 $\left.1,400 \mathrm{~cm}^{3}\right)$ が水平水路を飛び出した実験 2 （桜 島ボラ試料・勾配 25 度) が $12.2 \mathrm{~m}$, 実験 1 (桜川砂試料) が11.8m，そして実験 3 （桜島ボラ試料・勾配 35 度）が $10.4 \mathrm{~m}$ の順になった。なお, 実験 2 は水路から飛び出し た土砂が存在するが，ここでは水路末端までの值として 示した。図ー 9 は，前述したScheidegger (1973) が提 案した等価摩擦係数に基づいて, Hsü（1975）が示した 岩屑流のデータに，著者らが，近年国内で発生した土砂 流動現象のデータを追加プロットしたものである。地質 や地形条件等が異なる種々の事例を一つのグラフにまと めたものであるため，デー夕に相当量のばらつきは存在 するものの, 岩屑流に関して土量と等価摩擦係数の両対 数には線形の関係が認められる（Hsü，1975）。また， 岩屑流と近年国内で発生した主要な土砂流動現象に関し て比較すると，土量が同じならば移動体がほぼ飽和した 状態で発生した土砂流動現象が小さな等価摩擦係数にな ることが示されている。地すべり地形を呈していたり， 立木が傾き始めている等の前兆現象を捉えることにより, 地すべり・斜面崩壊発生場所があらかじめおおよそ推定 可能であり, かつ, 土砂移動現象が発生する前に, 何ら かの手段により等価摩擦角（等価摩擦係数の逆正接）を 推定することができれば，流下土砂の概ねの到達点が予 測可能となることから, 等価摩擦係数は重要な一つの指 標となり得る。

前章で述べた土砂流下実験における等価摩擦角 $\left(\phi_{a}\right)$ を算出すると, 実験 3 (Ex. 3) が18.1度, 実験 1 (Ex. 1) が13.4度, 実験 2 (Ex.2) が13.0度の順に小さくなっ た（図-10）。一方，質点ではなく大きさを持つ土砂の 移動現象において平均的に発揮されている等価摩擦係数 は, Okura et al. (2000) も指摘しているように, 崩壊 発生前および堆積時の重心間の関係で表現されると考え

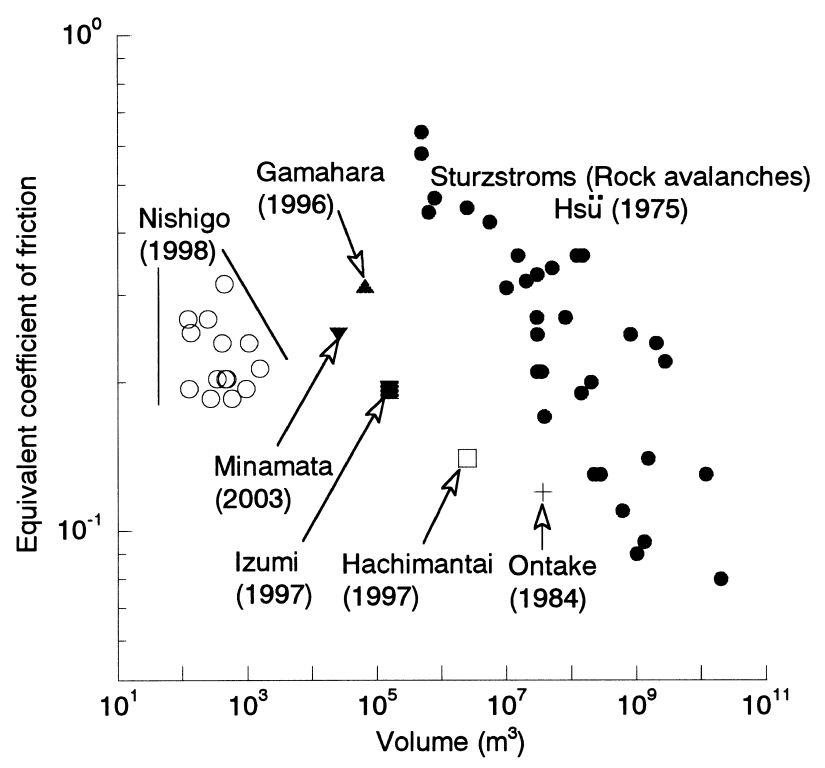

図一 9 等価摩擦係数と土砂流動現象の土量の関係（岩屑流 のデータはHsü (1975) より抜粋)

Fig. 9 Relationship between volume of mass flow phenomena and equivalent coefficient of friction (the data of sturzstroms were derived from Hsü (1975))

られる。そこで, 実験 1 （Ex.1）から 3 （Ex.3）に関 して崩壊発生前ならびに堆積時の崩壊土砂の重心間にお ける等価摩擦角 $\left(\phi_{a g}\right)$ を算出した (図-11)。その結果, 重心間の等価摩擦角は実験 1 (桜川砂) が22.8度, 実験 3 (桜島ボラ・35度傾斜) が 22.7 度, 実験 2 (桜島ボラ・ 25 度傾斜）が17.8度（ただし，水路を飛び出した礫に関 しては考慮していない）の順に小さくなり，通常の等価 摩擦角と, 実験 1 （Ex.1）および実験 3 （Ex. 3）の順 番が入れ替わった。このことに関しては本項最後に議論 したい。

前章までで確認したように，桜川砂試料では過剩な間 隙水圧が発生したが，桜川砂試料に比して透水性が大き い桜島ボラ試料では過剩な間隙水圧の発生は認められな かった。つまり，過剩間隙水圧の発生による有効垂直応 力の低下に伴うせん断抵抗の減少は，桜川砂試料でのみ 生じた。しかしながら，土砂の最大到達距離は，勾配25 度の桜島ボラ試料 (実験 2（Ex. 2)) が, 桜川砂試料 (実

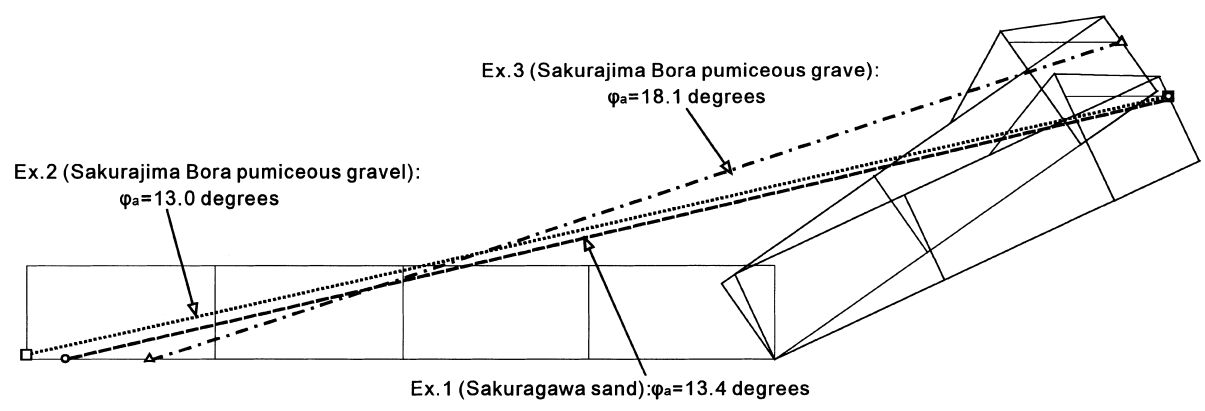

図一10 等価摩擦角（最大鉛直距離と水平距離の比の逆正接）

Fig. 10 Schematic illustration of obtained apparent friction angles 


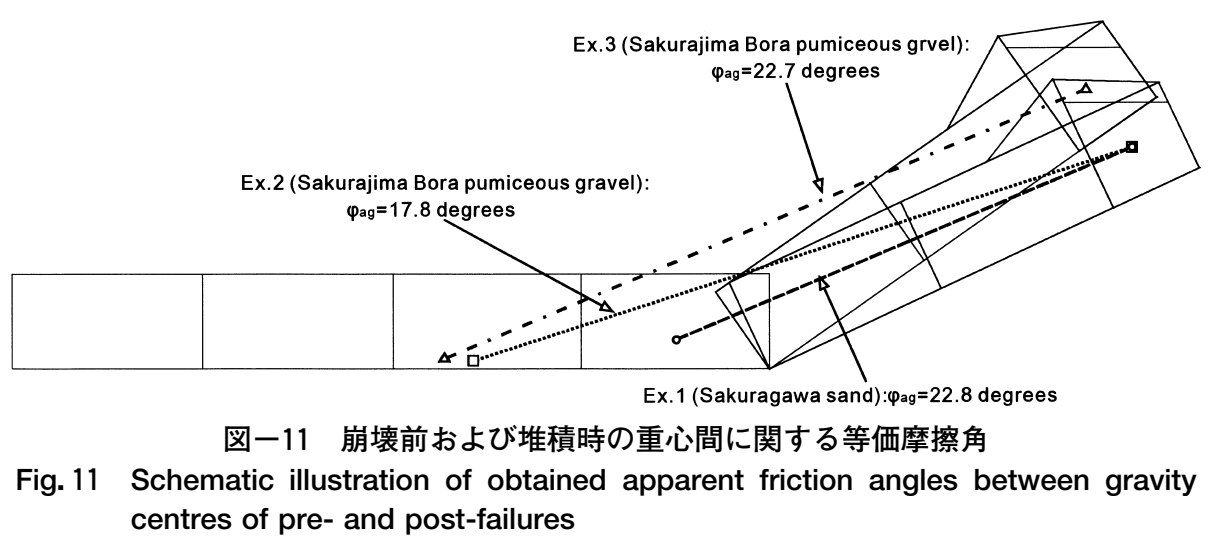

験 1 (Ex. 1))を上回った。また, 崩壊前および堆積時 の重心間の到達距離は，桜川砂試料（実験 1 (Ex. 1)) が4. $8 \mathrm{~m}$ と最小になった。これらについて，まず，供試 材料の違いの効果について検討する。桜島ボラ試料では, 過剩間隙水圧の発生はないものの, 供試体の単位体積重 量が小さいことから土粒子同士に働く有効垂直応力は 元々小さい。この桜島ボラ試料の飽和供試体を流下させ た場合，浮力の効果により土粒子がほぼ浮かんだような 状態になり, 発揮されるせん断抵抗が小さいことから運 動距離が大きくなったと考えられる。一方，桜川砂は， 流下土砂の先頭部では過剩間隙水圧を伴い遠くまで運動 した。しかし，先頭部以外では過剰な間隙水圧の発生は 認められず，勾配部を流下中に発揮されたせん断抵抗も あまり低下しなかったと考えられる。このため傾斜変換 点付近で堆積した。このことは, 桜島ボラ試料のように, 透水性が大きく過剩間隙水圧の発生が無視できると考え られる試料においても, 単位体積重量が小さい場合は水 流に乗って遠くまで運動することを示している。

続いて，同じ桜島ボラ試料に対して水路勾配を変えた ことの効果を検討する。勾配35度の実験 3 （Ex. 3）は, 流下させた供試体の初期位置エネルギーが大きい状態で あるため，流下時のエネルギー消費が勾配25度の実験 2 （Ex.2）と同様であるならば，より遠くまで運動するこ とになる。ところが, 重心間の水平移動距離は, 実験 3 (Ex. 3) が $6.8 \mathrm{~m}$, 実験 $2 （ \mathrm{Ex} .2 ）$ が $7.0 \mathrm{~m}$ と, 実 験 2 （Ex.2）が実験 $3 （ \mathrm{Ex} .3 ）$ を上回り遠くまで移動した。 また，先述の通り重心の等価摩擦角は実験 2 が実験 3 を 下回り，運動中に見かけ上発揮された抵抗力の平均值は 実験 2 （Ex.2）が小さかったことを意味する。これは, 勾配35度の実験 3 （Ex.3）では，勾配部を流下した土 砂が傾斜変換点で水平水路部へ流入する際に衝突によっ て急激な変形が進行することにより，特に鉛直方向成分 の運動エネルギーが消費されたことによると考えられる。

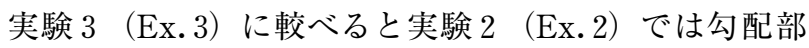
と水平部の連結が滑らかなため, 衝突や変形に伴うエネ ルギー消失が少なかったと考えられる。図 5 で示した通 り，実験 3 （Ex. 3）の流下土砂は実験 1 （Ex.1）およ び2（Ex. 2）に較べて, 流下土砂が分散することなく
一気に勾配部を流下し傾斜変換点での運動エネルギーは 最も大きかったと推定されるが，運動状態を示す指標で ある重心間の等価摩擦角で評価する場合, 衝突やそれに 伴った土塊の変形過程で散逸されるエネルギーの効果を 十分考慮する必要があることが, 本土砂流下実験でも確 認された。

等価摩擦係数と重心間の等価摩擦係数の関係について 検討する。桜川砂試料 (実験 1 (Ex.1)) と桜島ボラ試 料（勾配35度・実験 3 (Ex. 3)) について，等価摩擦角 は実験 1 （Ex.1）が，重心間の等価摩擦角に関しては 実験 3 （Ex. 3）が小さくなった。つまり，桜川砂試料 (実験 1 (Ex. 1))では, 土砂の最大到達距離は大きくなっ たが，長距離運動した土砂の量は多くなかった。一方， 桜島ボラ試料（実験 3 (Ex.3))では, 最大到達距離は それほど伸びなかったが，多くの土砂が長距離運動した。 こういった事実を踏まえると，土砂流動現象を理解する 上で, 次の二つの視点から運動特性を考える必要がある と思われる：

a）最大の到達距離 ; ならびに

b ）堆積する土砂の集合の程度。

ここで，a）の最大到達距離は，どこまで被害が及び 得るかを示すため，まず第一に考慮する必要があり，一 般に等価摩擦係数で評価される。続いてb）の堆積土砂 の集合の程度に関してであるが，これは，次のような視 点である。例えば防災施設あるいは家屋等の建造物が水 平水路左端部から $5 \mathrm{~m}$ の場所に存在したと仮定して, 実 験 1 （Ex. 1）と実験 3 （Ex. 3）ではこれらに与える衝 撃・破壊力は全く異なるということである。実験 1 （Ex.1）は端部から $5 \mathrm{~m}$ の場所に到達した土砂量は少な かったのに対し, 実験 3 （Ex.3）はその多くが到達し ており, これらに与える破壊力が大きかったと推定され, 実験 3 （Ex. 3）がより潜在的危険性が大きかったと考 えられる。そこで，著者らは，等価摩擦係数と重心間の 等価摩擦係数の比を, 運動特性指数 $(f)$ として定義す る。

$$
f=\frac{\tan \phi_{a}}{\tan \phi_{a g}}
$$


運動特性指数䄧1.0に近い場合は，等価摩擦角と重心間 の等価摩擦角の間に大きな差はなく, 流下土砂がほぼ塊 状を保った状態で到達し，破壊力も大きくなる可能性が 高い。一方， $f$ がよりささ場合は，土砂が分散する程 度が大きい可能性が高い。この $f$ を計算した結果，実験 1 の $f$ は 0.56 , 実験 2 が 0.71 , 実験 3 が 0.78 と実験 3 が最 大になり，土砂の分散する程度が少なかったことが示さ れた。ここで，実験 1 から実験 3 に関して，計測された 等価摩擦係数（到達する距離を表す指標）ならびに運動 特性指数（堆積する土砂の集合の程度を表す指標）の関 係を図-12に示す。等価摩擦係数 $\left(\tan \phi_{a}\right)$ が小さいほ ど，一方運動特性指数 $(f)$ が大きいほど，すなわち， このグラフ上で左上に位置するほど，到達距離も長く， 堆積する土砂の集合の程度も大きくなることを示し，よ り危険であることが示される。このことは，溪流におけ る防災施設の効果的な場所設定, 経済的かつ安全面から も信頼できる強度設計を検討する上で極めて重要な視点 であると考えられる。

\section{5. 結論}

桜川砂試料, 桜島ボラ試料に対し, 土砂流下実験を行っ た結果，次の結論が得られた。

・桜川砂試料では，勾配部を流下中の先頭土砂内部にお いて, 最大で土砂試料高さの 1.5 倍の圧力水頭值を得 た。このことは，流下中の土砂内部に扔ける過剩間隙 水圧の発生を実証的に示して扮り，現象を解析する上 でこのことに十分留意する必要性を示している。一方, 透水性の極めて大きな桜島ボラ試料については，過剩 間隙水圧の発生は認められなかった。

・勾配25度水路を用いた桜島ボラ試料の実験において, 到達距離が最も大きくなった。過剩間隙水圧の発生は 認められなかったものの，ボラ試料は単位体積重量が 小さく土粒子間の有効垂直応力が小さいため, 結果的 にせん断抵抗も小さく到達距離が大きくなったものと 考えられる。このことは, 流下する土砂試料の単位体 積重量が到達距離に強く影響を与えることを示してい る。

・勾配35度水路を用いた桜島ボラ試料の実験では，流下 土砂高さがピークを示してからその值がゼロに戻る時 間が最も短く，供試体はほとんど分散することなく勾 配水路を一気に流下した。一方，崩壊発生前扔よび堆 積時の重心間での等価摩擦係数は，勾配25度水路を用 いた桜島ボラ試料の実験がより小さな值を示し大きな 流動特性を示した。勾配35度の実験は, 崩壊発生前の 位置エネルギーが大きかったが，傾斜変換点での衝突 や変形によりエネルギーが消費されることにより等価 摩擦係数が大きくなったと推定された。

・最大到達距離ならびに堆積する土砂の集合の程度の両 視点からの現象理解が重要であると考え，流動土砂の 運動特性を表す指標として，等価摩擦係数と重心間の

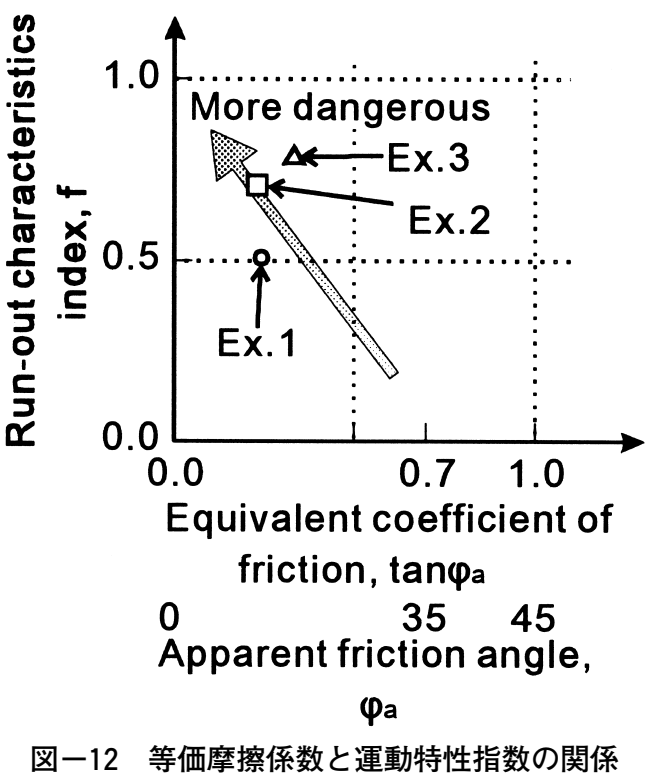

Fig. 12 Relationship between run-out characteristics index and equivalent coefficient of friction

等価摩擦係数の比を運動特性指数 $(f)$ として提案し た。

\section{謝辞}

本論文で扱った土砂流下実験に関して，故大倉陽一博 士（元独立行政法人森林総合研究所）は，水路の設計, 実験計画の立案に関し，主体的な役割を果たされた。こ こに記して媣謝の意を表すと共に，博士のご冥福を㧍祈 り致します。

本研究の進行にあたり，実験施設の整備に関して株式 会社共和技研の佐藤昭光氏には多大なるご協力を頂いた。 三森利昭博士ならびに岡本隆主任研究員（独立行政法人 森林総合研究所）には，解析の進め方，論文の構成に関 して，貴重なアドバイスを頂戴した。さらには，二名の 查読者には，詳細に渡り，丁寧かつ多くのご意見を賜っ た。ここに記して深謝致します。

\section{引用文献}

Bagnold, R. A. (1954) : Experiments on a gravity-free dispersion of large solid spheres in a Newtonian fluid under shear. Proceedings of the Royal Society of London. Vol.225A, Mathematical and physical sciences, pp. $49-63$.

Casagrande, A. (1971) : On liquefaction phenomenon, Géotechnique. Vol. 21, No. 3, pp. 197- 202.

Castro, G., and Poulos, S. J. (1977) : Factors affecting liquefaction and cyclic mobility. ASCE Journal of Geotechnical Engineering Division. Vol.103, No. GT6, pp. 501-516.

Hsü, K.J. (1975) : Catastrophic debris streams, sturzstroms generated by rockfalls. Geological Society of America Bulletin. Vol. 86, pp. $129-140$.

Hunt, B. (1994) : Newtonian fluid mechanics treatment of debris flows and avalanches. ASCE Journal of Hydraulic Engineering. Vol. 120, pp. $1350-1363$

石川芳治（1999）：地震による土石流の発生に関わる地形，地質条 件. 砂防学会誌 (新砂防), Vol. 51, No.1, pp. 35-42. 
Iverson, R. M. (1997) : The physics of debris flows. Reviews of geophysics. Vol. 35, pp. 245- 296.

Iverson, R. M., and Denlinger, R. P. (2001) : Flow of variably fluidized granular masses across three-dimensional terrain1. Coulomb mixture theory. Journal of Geophysical Research. Vol. 106, No. B1, pp. $537-552$.

Iverson, R. M., and Vallance, J. W. (2001) : New views of granular mass flows. Geology. Vol. 29, No. 2, pp. 115-118.

香川崇章（1978）：土構造物の模型振動実験における相似則．土木 学会論文報告集, No. 275, pp. 69-77.

Johnson, A.M., and Rahn, P.H. (1970) : Mobilization of debris flows. Zeitschrift für Geomorphologie (Annals of Geomorphology), Supplement Vol. 9, pp. 168-186.

地盤工学会（2002）: 土質試験の方法と解説. 社団法人地盤工学会. 第 6 編，pp. $330-423$.

Macedonio, G., and Pareschi, M.T. (1992) : Numerical simulation of some lahars from Mount St. Helens. Journal of Volcanological and Geothermal Research. Vol. 54, pp. 65-80.

岡田康彦，佐々恭二，福岡浩（2002）：リングせん断試験機を用い たせん断ゾーンに扔ける過㮃間隙水圧発生ポテンシャルにつ いて, 地すべり, Vol.39, No.3, pp.10-20.

Okura, Y., Kitahara, H., and Sammori, T. (2000) : Fluidization in dry landslides. Engineering Geology, Vol. 56, pp. 347-360.

Sassa, K. (1996) : Prediction of earthquake induced landslides, Special Lecture of $7^{\text {th }}$ International Symposium on Landslides, “Landslides," Balkema, Vol.1, pp. 115-132.

Sassa, K. (2000) : Mechanism of flows in granular soils. Proceedings of GeoEng2000, Melbourne, Vol. 1, pp. 1671-1702.

Sassa, K., Fukuoka, H., Scarascia-Mugnozza, G., and Evans, S.
(1996) : Earthquake-induced-landslides: Distribution, motion and mechanisms. Special Issue for the great Hanshin Earthquake Disasters, Soils and Foundations, pp. 53-64.

Savage, S. B. (1984) : The mechanics of rapid granular flows. Advanced Applied Mechanics, Vol. 24, pp. 289-366.

Savage, S. B., and Hutter, K. (1989) : The motion of a finite mass of granular material down a rough incline. Journal of Fluid Mechanics, Vol. 199, pp. 177-215.

Scheidegger, A.E. (1973): On the prediction of the reach and velocity of catastrophic landslides. Rock Mechanics. Vol. 5 , pp. $231-236$.

Shreve, R. L. (1966) : Sherman landslide, Alaska. Science, Vol. 154, pp. 1639-1643.

Shreve, R. L. (1968) : Leakage and fluidization in air-layer lubricated avalanches. Geological Society of America Bulletin, Vol. 79, pp. 653-658.

Shieh, C.L., Jan, C.D., and Tsai, Y.F. (1996) : A numerical simulation of debris flow and its application. Natural Hazards. Vol. 13, pp. $39-54$.

Takahashi, T. (1978) : Mechanical characteristics of debris flow. ASCE Journal of Hydraulic Engineering. Vol. 104, pp. $1153-$ 1169.

Takahashi, T. (1980) : Debris flow on prismatic open channel. ASCE Journal of Hydraulic Engineering. Vol. 106, pp.381396.

山田孝，南哲行，菊池英明，三浦郁人（2000）：複合型土石流の発 生に関与する地形要因についての統計的解析，砂防学会誌(新 砂防), Vol. 53, No.4, pp. 23-29.

（原稿受付2006年 1 月26日，原稿受理2006年10月18日） 